\title{
Transformation of deprived urban areas and social sustainability: A comparative study of urban regeneration and urban redevelopment in Barcelona and Seoul
}

The transformation of deprived urban areas is important for strengthening social sustainability in particular localities, and it is also instrumental in attracting new investments to cities. Speculative urban development, however, often ignores the social importance of localities and considers them mere economic assets that can be stripped of historical, social, and symbolic meaning and turned into easily marketed commodities. This article examines the somewhat contradictory role of the transformation of deprived urban areas in cities. It compares Barcelona and Seoul, two cities with different historical, cultural, and institutional contexts. The 22@ Activity District in Poblenou and Wangsimni New Town are explored as case studies to understand how urban regeneration and urban redevelopment are embedded in a particular locality and what consequences they have on social sustainability. Although the two cases differ in terms of planning approach, stakeholders, and institutional contexts, the findings suggest that the consequences for social sustainability were similar in both. The article argues that declining social cohesion and a lack of citizen participation were a consequence of speculative urban development, in which urban regeneration and urban redevelopment were instrumentalized to attract investments, strengthen economic competitiveness, and improve the city's global appeal rather than address diverse local challenges.

Keywords: citizen participation, social cohesion, social sustainability, urban redevelopment, urban regeneration 


\section{Introduction}

Cities compete to attract investments, jobs, events, and tourists to boost their economic growth and urban development, and to improve their quality of life. There is little evidence, however, that competition benefits everyone equally. In fact, the benefits of competition are often rather unevenly distributed across different social groups in the city (Brenner et al., 2012; Harvey, 2012). Moreover, environmental degradation, social and economic disparities, and declining civil rights are seen as a consequence of a competitive urban policy that prioritizes commodification of public space, privatization of social amenities and services, deregulation of urban planning, and the construction of iconic projects, along with city marketing (Short, 2004; Mayer, 2007). This market-driven urban development considers localities to be mere economic assets that can be stripped of historical, social, and symbolic meanings, and turned into easily marketed commodities (Balibrea, 2001; Short, 2004; Križnik, 2011). In this sense, the transformation of deprived urban areas has become instrumental in attracting new investments to cities (Smith, 2002; Shin \& Kim, 2016). At the same time, the improvement of deprived urban areas is also important for strengthening social sustainability in cities (Manzi et al., 2010; Colantonio \& Dixon, 2011; Ho et al., 2012).

This article examines the somewhat contradictory role that the transformation of deprived urban areas has in cities. It compares Barcelona and Seoul, two cities with rather different historical, cultural, and institutional contexts. Previous research suggests that in spite of these differences the transformation of what the Barcelona City Council and Seoul Metropolitan Government (SMG) considered to be underdeveloped urban areas was often instrumentalized to attract investments, strengthen economic competitiveness, and improve the global appeal of Barcelona (Marshall, 2000; Balibrea, 2001; Arbaci \& Tapada-Berteli, 2012; Dot Jutgla et al., 2012; Charnock et al., 2014) and Seoul (Cho, 2008; Kim, 2010; Križnik, 2011; Shin \& Kim, 2016). This was publicly legitimized as being of strategic importance for the city and seemingly beneficial for all citizens (Ajuntament de Barcelona, 2000, 2012; SMG, $2005,2010)$. This similarity regarding instrumentalization and legitimization is the starting point for comparing the transformation of deprived urban areas in Barcelona and Seoul and its consequences for social sustainability in individual localities.

Although urban development in Barcelona and Seoul is well studied, it has seldom been discussed from a comparative perspective; exceptions include Uršič and Križnik (2012), Colantonio et al. (2014), and Križnik (2014). The article begins with a discussion on the relationship between urban devel- opment and social sustainability to establish a framework for assessing the consequences of urban development for social sustainability in localities. Barcelona and Seoul are compared in terms of their position in the global urban system and their respective national urban systems, institutional contexts, and planning approaches.22@ Activity District (22@) in Barcelona's Poblenou and Wangsimni New Town (WNT) in Seoul are explored as an in-depth case study of urban regeneration in Barcelona and urban redevelopment in Seoul in terms of planning approach, stakeholders, and consequences for social sustainability. ${ }^{[1]}$ Finally, the findings are summarized, the conclusion is presented, and limitations of the study are discussed.

\section{Urban development and social sustainability}

Sustainable urban development is commonly addressed in terms of the "three-E framework," according to which sustainable economic growth of cities should be balanced with environmental protection and social equity (Mayer \& Knox, 2006: 324). Balancing the economy, the environment, and social equity requires negotiation between stakeholders, which implies that sustainable urban development also has an inherent political dimension. In contrast to the past, when sustainable urban development used to be reduced to its economic and environmental dimensions, a multi-dimensional approach, which recognizes the importance of social sustainability for long-term sustainable urban development, is now widely accepted (Dempsey et al., 2011; Dujon et al., 2013). One reason for the relatively little attention that social sustainability received earlier is related to the insufficient understanding of the relationship between social sustainability and urban development. Another reason lies in the often intangible social consequences of urban development, which eventually pose difficulties for implementing and assessing urban policy that promotes social sustainability.

Colantonio and Dixon (2011: 24) argue that social sustainability should be approached in terms of "traditional social policy areas and principles, such as equity and health, with emerging issues concerning participation, needs, social capital, the economy, the environment, and, more recently, with the notions of happiness, well-being, and the quality of life." In Colantonio and Dixon's view, urban policy that aims to strengthen social sustainability should improve the quality of everyday life; promote equal opportunities for social groups with different economic, social, and cultural backgrounds; foster social integration by addressing economic, social, and po- 
litical exclusion; sustain existing social and cultural structures in localities; encourage citizen participation in decision-making; and support self-management of localities. Integration of a broad array of policies - including those focusing on economics, social welfare, education, the environment, and urban planning - is therefore needed to strengthen social sustainability in cities (Dempsey et al., 2011).

Planning approaches that address the transformation of deprived urban areas, such as urban redevelopment or urban regeneration, are an important instrument to address social sustainability in cities (Williams \& Dair, 2007; Manzi et al., 2010; Colantonio \& Dixon, 2011; Ho et al., 2012). Apart from providing affordable housing, social amenities, and infrastructure, transformation of deprived urban areas can mitigate social inequalities and address social exclusion in localities by creating inclusive places where social groups with different backgrounds can meet and where communal life and shared identities can be created and reproduced (Forrest \& Kearns, 2001). Urban redevelopment, however, is focused on physical improvement and re-imaging of deprived urban areas, which are partly or entirely demolished and replaced with new urban development. This often leads to a massive displacement of residents and the collapse of their social networks. In contrast, urban regeneration addresses the economic, social, environmental, and physical transformation of deprived urban areas, where new urban development is integrated within existing social and urban fabric (Cho \& Križnik, 2017; Roberts et al., 2017). Ho et al. (2012: 127) argue that such a gradual and comprehensive approach is more appropriate "for enhancing the sustainability of the built environment."

Citizen participation is widely regarded as playing a critical role in strengthening social sustainability (Irvin \& Stansbury, 2004; Dempsey et al., 2011). It leads stakeholders to become better aware of various interests, problems, and opportunities in localities, as well as to learn to solve these challenges collectively. This can improve the quality of planning, legitimize decision-making, and also encourage citizens to actively use and appropriate places that are transformed with their participation (Cerar, 2014). Cho and Križnik (2017: 151) recognize "the necessity of building a robust partnership between the state and civil society" as an important step towards successful community-based urban development and stronger social sustainability in cities. In their view, planning approaches that aim to strengthen social sustainability should promote citizens' active involvement in decision-making and contribute to socially cohesive localities. These are characterized by low levels of social inequality, strong social connections and trust, and well-established communication and cooperation among citizens and public institutions (Larsen, 2013). In this way, the transformation of deprived urban areas can improve social interaction, trust, and solidarity among various stakeholders, as well as confidence in public institutions, which according to Manzi et al. (2010: 18) are the "core concepts and guiding principles for a localized social sustainability agenda."

Many cities in which citizens are excluded from decision-making face difficulties in maintaining their social and territorial cohesion (Brenner et al., 2012). Harvey (1989: 13) argues that these problems largely stem from what he calls "urban entrepreneurialism" and "ruinous inter-urban competition." As a result, urban development becomes increasingly speculative and instrumental in mobilizing "urban real-estate markets as vehicles of capital accumulation" (Smith, 2002: 446). In terms of capital accumulation, cities with a comparatively peripheral position in the global urban system are expected to face stronger pressures than dominant centres (Gugler, 2004; Short, 2004; Harvey, 2012). Taylor (2004) calls these cities "wannabe global cities," indicating their aspiration to challenge the established relations in the global urban system. Inter-urban competition and resulting speculative urban development can in turn negatively affect not only social sustainability in localities but also cities' long-term capacity to effectively address emerging social, economic, and environmental challenges (Wolfram, 2018).

\section{Research methodology}

In contrast to what she calls the "classical comparative approach," Sassen (2001: 348) argues that comparing cities in the global urban system requires a new methodology; one that is not based on standardization across cases, but that tries to track "a given system or dynamic ... and its distinct incarnations ... in different countries." This study follows her suggestion and compares Barcelona and Seoul to better understand the consequences of speculative urban development on social sustainability. Both cities formerly occupied a similar position in the global and national urban system in the past. Earlier research suggests that this affected the transformation of deprived urban areas, which was instrumentalized to attract investments, strengthen economic competitiveness, and improve the global appeal of Barcelona and Seoul (Marshall, 2000; Balibrea, 2001; Cho, 2008; Kim, 2010; Križnik, 2011; Arbaci \& Tapada-Berteli, 2012; Dot Jutgla et al., 2012; Charnock et al., 2014; Shin \& Kim, 2016). This was largely legitimized in public as being of strategic importance for the city and seemingly beneficial for all citizens (Ajuntament de Barcelona, 2000, 2012; SMG, 2005, 2010).

The similar instrumentalization and legitimization of urban development in relation to the position of both cities in the global urban system and their respective national urban systems constitutes the methodological starting point for a cross-cultural comparison of the transformation of deprived 
urban areas in Barcelona and Seoul. Although both have been discussed from a comparative perspective, earlier studies focused on the impact of inter-urban competition on urban management (Uršič \& Križnik, 2012), the role of multi-level urban governance for their economic resilience (Colantonio et al., 2014), or the grassroots responses to the globalization of Barcelona and Seoul (Križnik, 2014). These studies paid less attention to the impact of urban development on social sustainability, which is recognized as a major challenge for cities in the future (Dempsey et al., 2011; Wolfram, 2018). For this reason,22@ in Barcelona and WNT in Seoul are explored as an in-depth case study of urban development to understand how different planning approaches are embedded in a particular locality and what consequences they have on social sustainability. The assessment of social sustainability focuses on social cohesion and on the involvement of citizens in decision-making, which are recognized as the key principles of social sustainability (Forrest \& Kearns, 2001; Irvin \& Stansbury, 2004; Manzi et al., 2010; Cho \& Križnik, 2017).

The field research consisted of numerous site visits to Poblenou and Wangsimni between 2006 and 2012 to observe their social and urban transformation. During this period, semi-structured interviews were conducted with twelve interviewees from Barcelona and sixteen from Seoul, each of them belonging to one of five major stakeholders' groups. ${ }^{[2]}$ Two surveys - which included 148 respondents from Poblenou and ninety-five from Wangsimni - were carried out in 2006 and 2007, with the aim of comparing the consequences of the transformation of each locality on everyday life. These surveys were based on quota non-probability sampling, in which respondents were selected according to their sex, age, place of birth, education, and homeownership. ${ }^{[3]}$ Because this method does not allow generalization of the survey results to the overall population, these were complemented with in-depth interviews and extensive analysis of secondary sources. These included but were not limited to local government documents and reports, research papers on urban policy and planning, and various historical records about Poblenou and Wangsimni. Finally, the findings were discussed with field experts in both cities in order to avoid cultural bias in understanding and assessing the data, which is believed to be a major difficulty in cross-cultural studies (Hantrais \& Mangen, 1996).

\section{Case study: Barcelona and Seoul \\ 4.1 The institutional context of urban development in Barcelona and Seoul}

Barcelona and Seoul are the capitals of Catalonia and South Korea. Both used to occupy a similar position in the global urban system, which Gugler (2004) described as second-tier global cities. Taylor (2004) similarly ranked Barcelona and Seoul as thirty-second and forty-first, respectively, in terms of their global network connectivity based on his analysis of advanced producer services in the early 2000s. Other authors identified the comparably peripheral position of Barcelona and Seoul in the global urban system in the past (Beaverstock et al., 1999; Alderson et al., 2010; Csomós \& Derudder, 2013). In contrast to dominant centres, such as New York, London, or Tokyo, which Sassen (2001: 3) recognized as the "command points in the organization of the world economy," the importance of Barcelona and Seoul in the global urban system resulted from their role of connecting the national economy to global markets. Barcelona is a case of what Taylor (2004) calls an "inner wannabe city." For the past two decades, the strategic goal of the local government was to challenge the dominant position of Madrid in the national urban system by developing innovation, knowledge, and creative industries, as well as advancing communication, logistics, and transportation infrastructure (Ajuntament de Barcelona, 2012). The city tried to improve its position not only in relation to Madrid but also to other European and Mediterranean cities (Monclús, 2003; OECD, 2009). In contrast, Seoul used to be an example of an "outer wannabe city," trying to compete with Tokyo, Hong Kong, and Beijing by boosting advanced producer services and by promoting knowledge and cultural industries (Taylor, 2004). Although Seoul offers world-class communication and transportation infrastructure, improving the quality of life remains one of the main strategic goals of the local government (OECD, 2005; SMG, 2013).

In this way, both cities successfully transformed themselves from industrial national capitals into important post-industrial global cities over the past decade. Seoul in particular has managed to considerably strengthen its global "command-and-control function," whereas Barcelona maintains its competitive advantages despite the declining importance of European cities overall (Csomós \& Derudder, 2013: 346). Globalization has thus strengthened their role as national economic, social, cultural, and political centres, leading to a further concentration of population, and financial and political power. In 2014, about $63 \%$ of the Catalan population lived in the Barcelona Metropolitan Region and about $48 \%$ of South Koreans lived in the Seoul National Capital Region (Ajuntament de Barcelona, 2015; SMG, 2015a). At the same time, Barcelona is not only the Catalan capital, but also the second-largest Spanish city, and the rivalry with Madrid has always strongly affected urban development (Monclús, 2003). Both continue to attract major investments, knowledge and cultural industries, advanced producer services, jobs, and key R\&D and educational institutions in Catalonia and South Korea, although the importance of metropolitan regions has recently grown (Choe, 2005; OECD, 2005, 2009). 
This particular position of Barcelona and Seoul in the global and national urban system also affects the transformation of deprived urban areas, which has become increasingly instrumental in attracting investments to each city (Charnock et al., 2014; Shin \& Kim, 2016). The improvement of deprived urban areas in Barcelona dates back to the late nineteenth century, when large parts of the city centre were substantially transformed. Following this tradition, the local government introduced an innovative planning approach in the 1980s, which was "to deliver the renewal programme in the whole central district and tackle deprivation under a unique and integral vision" (Arbaci \& Tapada-Berteli, 2012: 292). This planning approach was extended to peripheral areas after the 1980s (Esteban, 2004). Successful improvement of deprived urban areas has become widely recognized as an essential part of the "Barcelona model" of urban development (Monclús, 2003). This refers to the large-scale urban regeneration of former industrial land into mixed-use and compact urban areas, which is sustained by public investments in social amenities and transportation infrastructure, the provision of high-quality public space, and well-established partnerships between various stakeholders (Marshall, 2000; Balibrea, 2001). Amid rising speculative urban development, these partnerships were challenged during the 2000s, which led some authors to write about the demise of the Barcelona model (Delgado, 2004; Degen \& García, 2012).

In contrast to Barcelona, the local government in Seoul used to promote the urban redevelopment of deprived urban areas rather than urban regeneration. ${ }^{[4]}$ Since the late 1970 s, a "wholesale clearance led by private investment was the distinct feature of Seoul's urban redevelopment policies" and was commonly followed by forceful displacement of residents to make way for speculative urban development (Kim \& Yoon, 2003: 587). Virtually all of downtown Seoul has been transformed in this way. During the past decade, however, the failure of urban redevelopment to address growing social, economic, and environmental challenges has prompted the local government to reconsider this planning approach and start improving deprived urban areas in a more comprehensive and inclusive manner (Cho, 2008; Kang, 2012; Križnik, 2013). Community-based urban regeneration became an integral part of urban development in Seoul after 2008 with the aim of involving citizens in planning and improving their neighbourhoods (SMG, 2013, 2015b).

Regarding the transformation of deprived urban areas, another important difference between Barcelona and Seoul is related to the institutional context of decision-making, in particular to the relation between public institutions and civil society. The local democracy in Barcelona progressed along with the democratization of Catalan and Spanish society during the 1970s, and the first democratic local elections were held in 1979. In South Korea, democratization preceded local democracy, and the first democratic local elections were held in 1995. Citizen participation, in which private and civil society stakeholders take part in decision-making along with the local government, has a longer tradition in Barcelona than Seoul. Neighbourhood associations in particular used to play an important role in improving Barcelona's deprived urban areas since the 1970s as broad grassroots coalitions, representing diverse local interests (Marshall, 2000; Esteban, 2004). In contrast, only property owners were able to take part in urban development in Seoul through the redevelopment associations, which were in practice controlled by construction corporations with active support from the local government (Kim, 2013; Shin \& Kim, 2016). In Seoul it is therefore difficult to talk about institutionalized citizen participation in the transformation of deprived urban areas before the late 2000s (Park, 2006; Cho \& Križnik, 2017).

\subsection{Barcelona:The 22@ Activity District in Poblenou}

The 22@ Activity District, introduced in 2000, is one of the largest urban regeneration projects undertaken in Barcelona in recent decades. It focuses on the transformation of $1,982,700 \mathrm{~m}^{2}$ of former industrial land in the industrial heart of Barcelona into a compact and mixed-use district, where strategic sectors - ICT, medical technology, biotechnology, energy management, and media and design - are to replace traditional industry. This means that the plan is expected to foster economic growth, improve economic competitiveness, and sustain Barcelona's transformation into a competitive global city. The Poblenou area was selected for this far-reaching transformation due to its proximity to the city centre, its low building density, the availability of vacant or underused land, accessibility, the underdeveloped local economy, its seemingly decaying social situation, and its long history of industrialization (Ajuntament de Barcelona, 2000, 2012; Oliva, 2003).

The industrialization of Poblenou dates back to the mid-nineteenth century, when large textile and machinery industries were established in the area due to good transportation and spatial conditions for industrial development. Many working-class neighbourhoods were built at that time along with the factories. Poblenou became known as the "Catalan Manchester" not only for its distinct industrial landscape, but also for its everyday life and local culture, characterized by a poor economic situation and low quality of life, vastly underdeveloped social amenities, and strong working-class solidarity and social activism (Arxiu Historic del Poblenou, 2001). The poor social and economic situation declined further after the 1960s, following the massive deindustrialization of the area and 
Table 1: Population growth in Poblenou.

\begin{tabular}{|c|c|c|c|c|c|c|c|c|}
\hline & 1970 & 1981 & 1986 & 1991 & 1996 & 2001 & 2006 & 2011 \\
\hline Population & 64,493 & 61,403 & 57,328 & 58,021 & 55,945 & 58,035 & 69,396 & 77,393 \\
\hline Growth & & $-5 \%$ & $-7 \%$ & $1 \%$ & $-4 \%$ & $4 \%$ & $28 \%$ & $4 \%$ \\
\hline
\end{tabular}

Source: Ajuntament de Barcelona (2015).

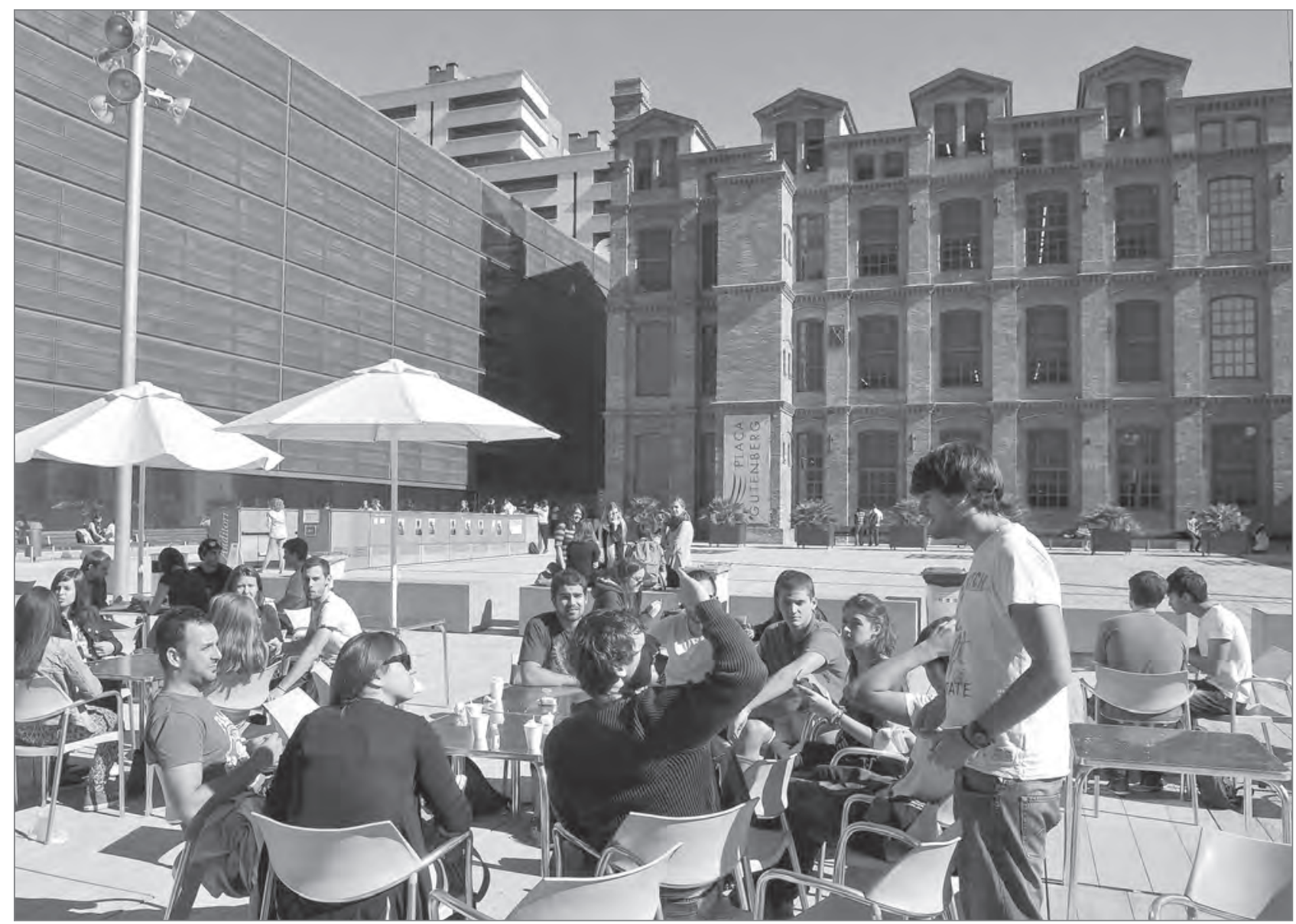

Figure 1:22@ aims to integrate the existing neighbourhood with the new urban development (photo: Barcelona Activa, Barcelona City Council).

relocation of major industries out of the city. From 1970 to 2001, around a quarter of residents left Poblenou due to the poor living conditions and unemployment (Table 1).

Improving the quality of life in Poblenou was therefore another important aim of 22@, apart from addressing the economic competitiveness of Barcelona. In this sense, urban regeneration was to transform the locality into a compact and mixed-use neighbourhood by providing new housing, green space, social amenities, and infrastructure, and by legalizing existing housing. Moreover, the industrial heritage was to be restored and integrated with the new urban development (Ajuntament de Barcelona, 2006). This was to be achieved primarily by focusing on the urban development of what the local government called strategic areas, which were to act as "motors for the transformation of the area, ... grant coherence," and allow for mixed-use with "sufficient continuity to the residential fabric" (Ajuntament de Barcelona, 2000: 18).

The local government accordingly publicly presented and legitimized 22@ as being of utmost importance for the future of Poblenou and the city (Ajuntament de Barcelona, 2012). The former head of the municipal urban planning department was clear about the anticipated role of 22@ for the city's longterm economic growth, as well as about its importance for improving the quality of life in the locality. In his view, the "new services amalgamation must return to the city, to the new knowledge-based city. Urban development regulations must allow this recovery of industry, and economic promotion policies must foster it ... to maintain our position among leading European cities, with new employees in new offices, with good communications ... and, in short, to improve citizens' quality of life" (Bragado i Acín, 2001: 42). 
Table 2: Population growth in Wangsimni.

\begin{tabular}{lllllllll}
\hline & 1979 & 1984 & 1989 & 1994 & 1999 & 2004 & 2009 & 2014 \\
\hline Population & 32,622 & 34,298 & 31,212 & 25,224 & 26,178 & 23,961 & 13,682 & 13,086 \\
\hline Growth & & $5 \%$ & $-9 \%$ & $-19 \%$ & $4 \%$ & $-8 \%$ & $-43 \%$ & $-4 \%$ \\
\hline
\end{tabular}

Source: SMG (2015a).

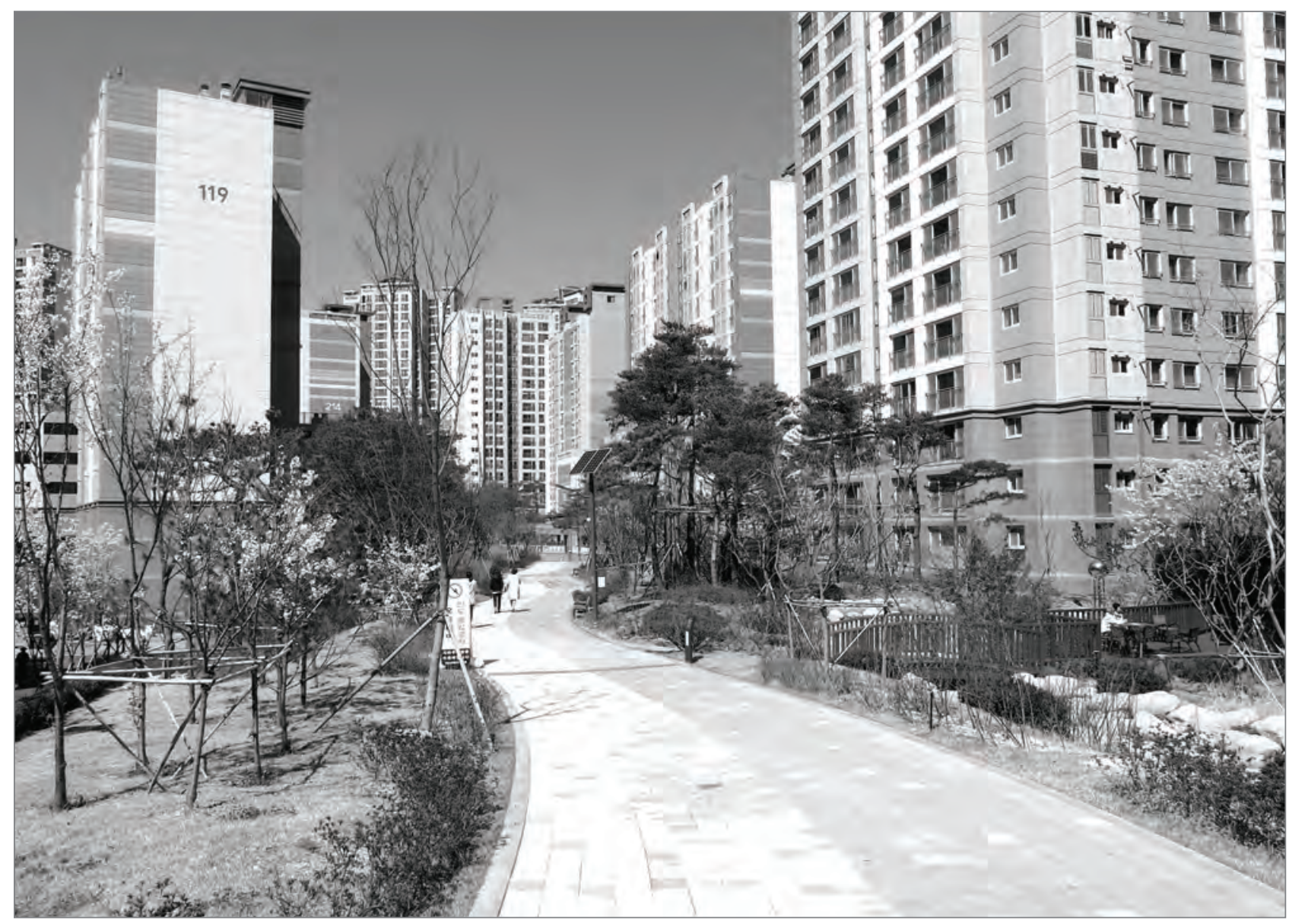

Figure 2: Wangsimni New Town has completely replaced the old neighbourhood (photo: Choi Hongyi).

Many of these initial aims have been achieved over the past decade. Poblenou has been transformed from a seemingly declining neighbourhood into a bustling mixed-use one, where different social and economic activities seem to be well integrated (Figure 1). Emerging knowledge and cultural industries and services, educational and R\&D facilities, and public institutions provide new business opportunities and jobs, and the residents can enjoy new public parks and use new social amenities and infrastructure (Ajuntament de Barcelona, 2012). However, contrary to the initial aims, the provision of these amenities did not follow the rapid pace of urban development, and the protection of industrial heritage against anticipated commercialization of the area also did not work as expected. Moreover, Charnock et al. (2014: 200) argue that in reality "the transformation process has been largely determined by rentier practices to capture monopoly rents" rather than by promoting knowledge industries or improving the quality of life in Poblenou. Considering the decline of jobs in traditional industrial and service sectors, growing housing costs, and the exclusion of residents from bureaucratized decision-making (Marrero Guillamón, 2010; Dot Jutgla et al., 2012), it is not surprising that $22 @$ has also resulted in negative consequences for everyday life in Poblenou and triggered a grassroots mobilization against the transformation of the locality (Križnik, 2014).

\subsection{Seoul: Wangsimni New Town}

At first glance, WNT seems far less important for Seoul than 22@ is for Barcelona. The urban redevelopment of a small mixed-use area of $324,000 \mathrm{~m}^{2}$ into a new residential and commercial neighbourhood was only one among many similar projects that were constructed all over the city throughout the past decade. WNT, however, is a pilot project of New 
Table 3: Perception of everyday life and urban development in Poblenou and Wangsimni.

\begin{tabular}{lll}
\hline & Poblenou & Wangsimni \\
\hline Workplace located in the neighbourhood & $58 \%$ & $66 \%$ \\
\hline Frequently spending weekends in the neighbourhood & $66 \%$ & $69 \%$ \\
\hline Meeting neighbours on a daily basis & $28 \%$ & $32 \%$ \\
\hline Meeting neighbours on a weekly basis & $20 \%$ & $41 \%$ \\
\hline Good relations with neighbours & $69 \%$ & $65 \%$ \\
\hline Perception of neighbourhood as an underdeveloped area & $29 \%$ & $64 \%$ \\
\hline Very familiar with 22@/WNT & $17 \%$ & $8 \%$ \\
\hline
\end{tabular}

Town Development - an initiative that the local government introduced in 2002 with the intention of balancing urban development, creating new jobs and investment opportunities, and improving Seoul's economic competitiveness (Kim, 2010; Kang, 2012). This was expected to resolve regional disparities by addressing problems of urban sprawl, housing, lacking infrastructure and social amenities, and shrinking employment. It focused on what the local government considered underdeveloped urban areas in northern Seoul in order to balance its economic growth and urban development with the more affluent southern part (SMG, 2010). The deputy mayor for public affairs and one of its masterminds emphasized the strategic importance of New Town Development. In his view, the "main rationale behind the New Town initiative was that it was the time to focus on the revitalization of existing neighbourhoods rather than on sindosi development. ... Therefore, the existing city had to be redeveloped based on wide-range, comprehensive plans that took into account the overall demand for urban infrastructure" (cited in Kim, 2010: 95). ${ }^{[5]}$ Wangsimni was chosen to be one of the three pilot projects that were expected to showcase the benefits of this new planning approach, in which the social, economic, and environmental dimensions of urban redevelopment would be addressed in a comprehensive way (Cho \& Križnik, 2017).

Wangsimni used to be located on the outskirts of pre-modern Seoul. During the city's rapid industrialization in the 1960s, the locality became packed with small industries, which nevertheless experienced a slow but steady economic decline over the subsequent decades (Seoul Museum of History, 2009). From 1979 to 2004, Wangsimni lost 27\% of its population (Table 2). The seemingly deteriorating economy and poor living environment, along with its good accessibility and proximity to the downtown area, are among the main reasons that the local government selected the area for New Town Development (SMG, 2005). Yet this decision seems to have been less a result of the actual needs of the residents than the economic and political interests of the local government, particularly in relation to the nearby Cheonggyecheon Res- toration. ${ }^{[6]}$ Although the two were formally not related, the Cheonggyecheon Restoration had a direct influence on the decision to select Wangsimni as the pilot project and show the seemingly positive impacts of the restoration on the deprived urban areas (Kim, 2010).

WNT was planned as a mixed-use residential and commercial area with many social amenities and extensive green areas. The local government presented the plan as an "environmentally friendly urban centre community in harmony with Cheonggye Stream" and as a "rural area in the heart of the metropolis... a new community where residents of different generations and social groups could coexist" (SMG, 2005: 22). In reality, however, urban redevelopment has led to the full-scale demolition of the old and construction of a new neighbourhood, which has little in common either with the announced goals of the plan or with the interests of its stakeholders. This inconsistency between the plan and its actual implementation was largely a consequence of the changing attitude of the local government, which had initially called for the improvement of the existing urban areas and tried to listen to different stakeholders, but finally focused on the speculative interests of property owners (Cho, 2008; Kim, 2010). The local government thus aimed to implement the plan as quickly as possible because this was considered of strategic importance for the city (SMG, 2010).

WNT, which is nearing completion, offers new residential and commercial space and social amenities, and has greatly improved the living environment for new residents (Figure 2). The transformation has not only significantly changed the living environment in Wangsimni, but has also altered the established social structure and economic organization, and had negative consequences for everyday life in the locality. Most of the former residents were displaced, and the large-scale demolition negatively affected the local economy and communal life, and contributed to a loss of jobs in the traditional industrial and service sectors (Kim, 2010). However, in contrast to the extensive grassroots mobilization in Poblenou, protests by small property owners and tenants in Wangsimni emerged late 
and were focused on protecting their material interests rather than challenging the transformation of the locality (Križnik, 2014).

\subsection{Consequences and perception of urban development}

The survey results and interviews reveal that Poblenou and Wangsimni used to have a well-developed economic and communal life before the urban development started. This largely contrasts with the notion of a deprived urban area, which the local government used in public to legitimize the transformation of Poblenou and Wangsimni (Ajuntament de Barcelona, 2000; SMG, 2005). The survey showed that 66\% of respondents in Poblenou and 69\% in Wangsimni claimed that they frequently spent their free time in the locality. At the same time, about half of all respondents had their workplace in the neighbourhood, which together points towards a strong place attachment (Livingston et al., 2010). Twenty-eight per cent of respondents in Poblenou and 32\% in Wangsimni met their neighbours on a daily basis, whereas $20 \%$ of respondents in Poblenou and $41 \%$ in Wangsimni met them on a weekly basis. Sixty-nine per cent of respondents in Poblenou and 65\% in Wangsimni also considered their relationships with neighbours excellent or good (Table 3). The survey suggests that everyday life in Poblenou and Wangsimni used to be characterized by relatively strong social cohesion in the past, which is of key importance for social sustainability in localities (Manzi et al., 2010; Colantonio \& Dixon, 2011).

If the local governments had been concerned with social sustainability, the transformation of Poblenou and Wangsimni should have maintained or strengthened social cohesion in the locality. Indeed, one of the aims of 22@was to integrate new urban development with existing social and urban fabric by legalizing 4,614 housing units, which were earlier considered illegal due to the exclusive industrial land use (Ajuntament de Barcelona, 2000). Such an approach could have sustained the social connections, place attachment, and collective identity in Poblenou. However, many of these residential buildings were demolished due to speculative urban development. At the same time, old industrial buildings were also designated for demolition, which has become a major source of conflict between the local government and residents. They considered industrial heritage to be an important part of their "collective memory of the history of industrialization" (Grupo de trabajo sobre patrimonio del Fòrum Ribera del Besos, 2003: 7). Grassroots mobilization - aiming to preserve old factories and the collective identity of Poblenou - has forced the local government to designate a larger number of industrial buildings as cultural heritage and eventually transform some of them into social amenities (Ajuntament de Barcelona, 2006).

The residents of Poblenou also faced expropriations, displacement, a decline in jobs, and rising housing costs (Assemblea de Joves del Poblenou i Assemblea d'Endavant (OSAN) del Poblenou, 2011; Dot Jutgla et al., 2012). The new urban development has seen more than twenty thousand residents move to Poblenou over the past decade, which is equivalent to onethird of the neighbourhood's population in 2000 (Table 1). During the same period, the population of Sant Martí district, where Poblenou is located, has grown by only $12 \%$ (Ajuntament de Barcelona, 2015). The actual number of new residents could be even higher because some old residents had to leave the area due to the growing costs and lack of affordable housing. From 2000 to 2010, the Sant Martí district saw the fastest growth of rents in the entire city. During this period, the average rental prices increased by $212 \%$, which was higher than the average increase of $187 \%$ in Barcelona (Ajuntament de Barcelona, 2015). To address the issue of affordable housing, the local government planned to build four thousand social housing units, with $25 \%$ of them for the residents of Poblenou. By 2010, 1,520 units were actually completed (Ajuntament de Barcelona, 2012). As a result, residents started to perceive the ongoing transformation of the locality as a purposeful attempt on the part of the local government to change the existing social structure and collective identity of Poblenou (L'Associació de Veïns, 2003). This intensified conflicts between some groups of residents and the local government (Križnik, 2014).

In contrast to Poblenou, where the majority of residents stayed in the locality and part of the residential and industrial buildings were preserved, Wangsimni was completely demolished. More than ten thousand residents, or about $45 \%$ of its total population in 2004, have been forced to leave the locality over the past decade (Table 2). During this period, the Seongdong-gu district, where Wangsimni is located, has only seen a minimal decrease in the population (SMG, 2015a). Among those that left were mostly tenants from low-income households. Due to the rising housing costs, these residents have little chance of returning once the construction of WNT is completed (Lee, 2009; Kang, 2012). In this regard, WNT differs little from earlier urban development in Seoul, where fewer than $20 \%$ of old residents usually return to a new neighbourhood (Shin \& Kim, 2016). Such massive displacement of residents can have a highly negative impact on social sustainability in localities (Manzi et al., 2010).

The transformation of Poblenou and Wangsimni also resulted in the decline of jobs in the traditional industrial and service sectors. In 1999, 1,661 industrial establishments accounted 
for 23\% of all establishments in Poblenou. After 22@ got underway in 2000 , their number declined by $21.6 \%$ to 1,302 by 2004 and then continued to decline over the following years (Ajuntament de Barcelona, 2008). Although 56,000 new jobs were reportedly created during the 2000s (Ajuntament de Barcelona, 2012), these were mostly taken by new residents or commuters and are inaccessible to those residents that used to work in traditional industries and services. The situation in Wangsimni was even more difficult, where industrial establishments accounted for $40.5 \%$ of the total in 2004 (Seongdong-gu District Office, 2006). Most of them were very small and organized as a networked industrial cluster, where physical proximity and direct contacts were essential for businesses (Cho \& Križnik, 2017). After the large-scale demolition of Wangsimni, it was impossible to preserve these social and productive networks, and many were forced to relocate or close down. By 2012 there was virtually no industry in Wangsimni anymore. Earlier studies suggest that the traditional industrial and service sectors in Barcelona and Seoul had an important impact on the formation of social cohesion in localities (Nahm, 2001; Marrero Guillamón, 2010). Their decline negatively affected both economic and social sustainability in Poblenou and Wangsimni.

In contrast to Poblenou, where grassroots mobilization against the economic and social consequences of new urban development started as early as 2000, the residents in Wangsimni initially supported WNT. Although they perceived it as a good place to live, they also saw Wangsimni as an underdeveloped area lacking business opportunities. This, in turn, made them initially support the plan (Table 3). Kim (2010) suggests that this support was also related to the fact that the local government managed the planning, which made the residents believe that WNT was presumably about public interests. Rising property values, which the residents expected would bring them significant financial gains, additionally contributed to their support. From 2002 to 2007, the land prices in Wangsimni increased by $111 \%$, whereas the average increase of land prices in Seoul was 55\% during the same period (Kang, 2007). This significantly changed after 2006, according to the interviewees, because of the slow implementation of the plan, financial losses, rising housing costs, and corrupt practices of redevelopment associations. As a result, some property owners and groups of tenants started actively contesting the plan's implementation (Kim, 2010; Križnik, 2014).

The survey shows that, although at different points, the residents of Poblenou and Wangsimni perceived the new urban development as being in the interest of property owners, private corporations, or the local government, rather than in their own interest (Table 3). The fact that 22@was planned without citizen participation and that the local government initially made little effort to involve residents in decision-making further strengthened this perception in Poblenou (Degen \& García, 2012). For the majority of residents, the main problem was not the urban development itself, but the lack of their involvement in decision-making (Oliva, 2003; Marrero Guillamón, 2010). The rapid urban development on the one hand and slow improvement of social amenities on the other intensified the negative perception of 22@ according to the interviewees. In contrast to Poblenou, the local government in Seoul tried to involve residents in planning WNT. However, the slow process of citizen participation with few tangible results, along with pressure from redevelopment associations to build WNT as quickly as possible, forced the local government to finally exclude residents from decision-making. This was beneficial for speculative property owners and private corporations but "significantly unfair for property owners who are against the project or for renters” (Kim, 2010: 154). Lee (2006), however, points out that the actual involvement of residents was below expectations. Some had no time, whereas others might have realized that they had no voice in a process dominated by redevelopment associations.

It is not surprising that the survey respondents perceived the transformation of their neighbourhood rather negatively, although many were not very familiar with the details of both plans. Only 6\% of survey respondents in Poblenou believed that 22@ reflected residents' interests, whereas 53\% thought that the plan was about the interests of private corporations and the local government. In Wangsimni 37\% of respondents, most of them property owners, believed that WNT was in their interest (Table 3). The survey findings and interviews suggest that 22@ and WNT have consequently contributed to growing distrust between the residents and public institutions, which does not contribute to social sustainability (Manzi et al., 2010; Dempsey at el., 2011).

\section{Conclusion}

There are differences between 22@ and WNT in terms of the planning approach, stakeholders, and institutional contexts. The former is an example of comprehensive long-term urban regeneration, which aims to integrate new urban development with the existing social and urban fabric in Poblenou. The local government initially prepared and implemented the plan in partnership with the private sector without much citizen participation. The latter is an example of short-term urban redevelopment, where the locality was completely demolished and replaced with new urban development. Although the residents were partly involved in decision-making at the begin- 
ning, it was the private corporations, supported by the local government, that dominated the planning and implementation process. In spite of these significant differences, the research results suggest that 22@ and WNT had similar consequences for social sustainability in the locality, especially on social cohesion and the involvement of citizens in decision-making.

Everyday life in Poblenou and Wangsimni used to be characterized by strong social connections and place attachment, as well as a distinct local culture and collective identity. Both of the planning approaches, however, did little to sustain these social and cultural structures, which are important for strengthening social cohesion in the locality. New urban development, which led to the demolition of existing residential and industrial areas, loss of jobs in traditional industrial and service sectors, decline of communal life, and rising housing costs, contributed to the decline of social cohesion in Poblenou and Wangsimni rather than strengthening it. Although 22@ and WNT did create new jobs, provide new housing and public space, and improve social amenities and infrastructure, this was not equally beneficial for everyone, which has in turn negatively affected the perception of the transformation among some groups of residents. These perceived the new urban development as mainly being in the interests of the local government and private corporations, which has consequently weakened their confidence in public institutions. This was further undermined by the exclusion of the residents from decision-making.

Social sustainability is a rather multifaceted concept that is not easy to assess. This is even more difficult in the case of ongoing urban development, such as 22@ or WNT, where long-term consequences cannot yet be fully observed. Nevertheless, the lack of citizen participation along with a decline in social cohesion - two major dimensions of a localized social sustainability agenda - has been clearly identified in this study. Although there are important differences between the two planning approaches, in both cases the failure of 22@ and WNT to address social sustainability was a result of speculative urban development, where the transformation of deprived urban areas was instrumentalized to attract investments, strengthen economic competitiveness, and improve the global appeal of the city as a whole. Both plans were legitimized in public as seemingly beneficial to all citizens, whereas in reality the main beneficiaries were property owners and private corporations. The findings therefore show that speculative urban development can negatively affect social sustainability, regardless of the planning approach used. However, this study is limited due to the ongoing transformation of Poblenou and Wangsimni. A follow-up study would be needed to determine subsequent changes in the planning approach over a longer period and fully assess the long-term impact of the transformation on social sustainability in Barcelona and Seoul.

Blaž Križnik

Hanyang University, Graduate School of Urban Studies, Seoul,

Republic of Korea

E-mail: blaz@hanyang.ac.kr

\section{Notes}

${ }^{[1]}$ This study uses English terms for the particular planning approaches used in Barcelona and Seoul. Although 22@ was introduced as an urban renovation project (Catalan: renovació urbana), the English documents and literature refer to it as urban regeneration (Ajuntament de Barcelona, 2000; 2012; Charnock et al., 2014). WNT is referred to as urban redevelopment (Korean: dosijaegaebal; SMG, 2010; Kim, 2010; Križnik, 2014).

${ }^{[2]}$ In Barcelona the interviews included six interviewees representing civil society (the Poblenou Neighbours Association, the Historic Archive of Poblenou, the Commission Against 22@, and Forum Ribera del Besòs), three representing the local government (the Barcelona City Council, the Sant Martí District Council, and Barcelona Regional), one from the private sector (Network 22@), and two experts (UPC and laaC). In Seoul five interviewees represented civil society (from the Committee for Community Development in Wangsimni, the Korean Council for Local Agenda 21, KOCER, and the Hope Institute), three were from local government (SMG and the Seoul Museum of History), four represented the private sector (the 2nd and 3rd Redevelopment Association in Wangsimni, the Association of Wangsimni Industry and Merchants, and Dongyang Purena), and four were experts (SDI, SNU, UOS, and Konkook University).

[3] The administrative units of El Poblenou and Wangsimni 1-dong were most affected by 22@ and WNT. In 2008 and 2006 they had populations of 30,949 and 14,099, which was the basis for the survey sampling (Ajuntament de Barcelona, 2008; SMG, 2015a).

${ }^{[4]}$ Barcelona and South Korea formalized these planning approaches in 1976, when the Barcelona City Council passed the General Metropolitan Plan, which provided a legal framework for urban regeneration of deprived urban areas, and the Urban Redevelopment Act was introduced in South Korea (Degen \& García, 2012; Kim, 2013).

${ }^{[5]}$ Sindosi refers to new cities built in the Seoul metropolitan region in recent decades to address shortages in housing, social amenities, and infrastructure in Seoul.

[6] Cheonggyecheon Restoration is another strategic project, introduced in 2002, which transformed the former Cheonggye Expressway into a five-kilometre-long urban park, with the restored Cheonggye Stream at its centre. Although it greatly improved the environmental conditions in downtown Seoul and restored part of the historical and cultural heritage, it has also been criticized for lacking environmental authenticity and contributing to the commercialization of nearby areas (Križnik, 2011). 


\section{Acknowledgments}

This work was supported by the research fund of Hanyang University (HY-2017). The research was also supported by the Seed Program for Korean Studies through the Ministry of Education of the Republic of Korea and the Korean Studies Promotion Service of the Academy of Korean Studies (AKS-2015-INC-2230013). An early draft was presented at the 2014 AESOP Annual Congress in Utrecht, the Netherlands. The author thanks Petra Očkerl for translating this article into Slovenian and Simona Lapanja for reviewing the translation.

\section{References}

Ajuntament de Barcelona (2000) Modification of the PGM (General Municipal Plan) for the renovation of the industrial area of Poblenou. Barcelona.

Ajuntament de Barcelona (2006) Modificaciò del Pla especial de protecció del patrimoni arquitectònic històric-artístic de la Ciutat de Barcelona al Districte de Sant Martí. Patrimoni Industrial del Poblenou. Barcelona.

Ajuntament de Barcelona (2008) Guies estadístiques. Sant Martí en xifres. Barcelona.

Ajuntament de Barcelona (2012) 22@ Barcelona plan. Barcelona.

Ajuntament de Barcelona (2015) Anuari estadístic de la Ciutat de Barcelona 2015. Barcelona.

Alderson, A. S., Beckfield, J. \& Sprague-Jones, J. (2010) Intercity relations and globalisation: The evolution of the global urban hierarchy, 1981-2007. Urban Studies, 47(9), pp. 1899-1923. DOI: $10.1177 / 0042098010372679$

Arbaci, S. \& Tapada-Berteli, T. (2012) Social inequality and urban regeneration in Barcelona city centre: Reconsidering success. European Urban and Regional Studies, 19(3), pp. 287-311. DOI:10.1177/0969776412441110

Arxiu Històric del Poblenou (2001) El Poblenou: més de 150 anys d'història. Barcelona.

Assemblea de Joves del Poblenou i Assemblea d'Endavant (OSAN) del Poblenou (2011) Torres més altes han caigut: el model 22@ al descobert. Research report. Barcelona.

Balibrea, M. P. (2001) Urbanism, culture and the post-industrial city: Challenging the "Barcelona model." Journal of Spanish Cultural Studies, 2(2), pp. 187-210. DOI: 10.1080/14636200120085174

Beaverstock, J. V., Smith, R. G. \& Taylor, P. J. (1999) A roster of world cities. Cities, 16(6), pp. 445-458. DOI: 10.1016/\$0264-2751(99)00042-6

Bragado i Acín, G. (2001) La renovación del Poblenou: una aproximación urbanística al districto de actividades 22@bcn. In: Ajuntament de Barcelona (ed.) Barcelona, metrópolis mediterrania: Ciudad del conocimiento, pp. 28-34. Barcelona.

Brenner N., Marcuse P. \& Mayer M. (2012) Cities for people, not for profit: Critical urban theory and the right to the city. London, Routledge.

Cerar, A. \& Tančič, M. (2014) From reaction to initiative: Potentials of contributive participation. Urbani izziv, 25(1), pp. 93-106. DOI: 10.5379/urbani-izziv-en-2014-25-01-002

Charnock, G., Purcell, T. F. \& Ribera-Fumaz, R. (2014) City of rents: The limits to the Barcelona model of urban competitiveness. International Journal of Urban and Regional Research, 38(1), pp. 198-217. DOI: $10.1111 / 1468-2427.12103$
Cho, I. S. \& Križnik, B. (2017) Community-based urban development: Evolving urban paradigms in Singapore and Seoul. Singapore, Springer. DOI: 10.1007/978-981-10-1987-6

Cho, M. R. (2008) Seoul-si New Town saeobui pyeonggawa daean mosaek. Journal of Korea Association of Real Estate Law, 17, pp. 47-56.

Choe, S. C. (2005) The impacts of globalization on the urban spatial-economic system in Korea. In: Richardson, H. W. \& Bae, C. H. (eds.) Globalization and urban development, pp. 59-78. Berlin, Springer. DOI: $10.1007 / 3-540-28351-X$

Colantonio, A., Burdett, R. \& Rode, P. (2014) Transforming urban economies: Policy lessons from European and Asian cities. London, Routledge.

Colantonio, A. \& Dixon, T. (2011) Urban regeneration \& social sustainability: Best practice from European cities. Oxford, Wiley-Blackwell.

Csomós, G. \& Derudder, B. (2013) European cities as command and control centres, 2006-11. European Urban and Regional Studies, 21(3), pp. 345-352. DOI: 10.1177/0969776412453149

Degen, M. \& García, M. (2012) The transformation of the "Barcelona model": An analysis of culture, urban regeneration and governance. International Journal of Urban and Regional Research, 36(5), pp. 1022 1038. DOI: 10.1111/j.1468-2427.2012.01152.x

Delgado, M. (2004) La otra cara del Fòrum de les cultures S. A. Barcelona, Edicions Bellaterra.

Dempsey, N., Bramley, G., Power, S. \& Brown, C. (2011) The social dimension of sustainable development: Defining urban social sustainability. Sustainable Development, 19(5), pp. 289-300. DOI: 10.1002/sd.417

Dot Jutgla, E., Pallares-Barbera, M. \& Casellas, A. (2012) Gentrificació productiva, desindustrialització i relocalització industrial. Treballs de la Societat Catalana de Geografia, 73, pp. 27-52. DOI:10.2436/20.3002.01.2

Dujon, V., Dillard, J. \& Brennan, E. M. (eds.) (2013) Social sustainability. A multilevel approach to social inclusion. London, Routledge.

Esteban, J. (2004) The planning project: Bringing value to the periphery, recovering the centre. In: Marshall, T. (ed.) Transforming Barcelona, pp. 111-150. London, Routledge.

Forrest, R. \& Kearns, A. (2001) Social cohesion, social capital and the neighbourhood. Urban Studies, 38(12), pp. 2125-2143. DOI: $10.1080 / 00420980120087081$

Grupo de trabajo sobre patrimonio del Fòrum Ribera del Besòs (2003) Poblenou, conjunto histórico industrial. El Poblenou, 9, p. 7.

Gugler, J. (ed.) (2004) World cities beyond the West: Globalization, development and inequality. Cambridge, Cambridge University Press.

Hantrais, L. \& Mangen, S. (1996) Method and management of cross-national social research. In: Hantrais, L. \& Mangen, S. (eds.) Cross-national research methods in the social sciences, pp. 1-12. London, Pinter.

Harvey, D. (1989) From managerialism to entrepreneurialism: The transformation in urban governance in late capitalism. Geografiska Annaler, 71(1), pp. 3-17. DOI: 10.1080/04353684.1989.11879583

Harvey, D. (2012) Rebel cities. London, Verso.

Ho, D. C. W., Yau, Y., Law, C. K., Poon, S. W., Yip, H. K. \& Liusman, E. (2012) Social sustainability in urban renewal: An assessment of community aspirations. Urbani izziv, 23(1), pp. 125-139.

DOI: 10.5379/urbani-izziv-en-2012-23-01-005

Irvin, R. A. \& Stansbury, J. (2004) Citizen participation in decision making: Is it worth the effort? Public Administration Review, 64(1), pp. 55-64. DOI: $10.1111 /$ j.1540-6210.2004.00346.x 
Kang, W. (2012) New town project of Seoul, Korea: An evaluation and future directions. Journal of the Korean Urban Management Association, 25(4), pp. 153-173.

Kang, Y. D. (2007) New Town land prices skyrocket 4 to 10 times higher than Seoul average. Yonhap News, 13 Nov. 2007.

Kim, J. (2010) Mobilizing property-based interests: Politics of policy-driven gentrification in Seoul, Korea. Doctoral thesis. Chicago, University of Illinois.

Kim, K. J. \& Yoon I. S. (2003) Urban renewal and change of the 20th century Seoul. In: Kim, K. J. (ed.) Seoul, twentieth century: Growth \& change of the last 100 years, pp. 543-596. Seoul, Seoul Development Institute.

Kim, S. H. (2013) Changes in urban planning policies and urban morphologies in Seoul, 1960s to 2000s. Architectural Research, 15(3), pp. 133-141. DOI: 10.5659/AIKAR.2013.15.3.133

Križnik, B. (2011) Selling global Seoul: Competitive urban policy and symbolic reconstruction of cities. Revija za sociologiju, 41(3), pp. 291312. DOI: 10.5613/rzs.41.3.2

Križnik, B. (2013) Changing approaches to urban development in South Korea, From "clean and attractive global cities" towards "hopeful communities." International Development Planning Review, 35(4), pp. 395418. DOI: 10.3828/idpr.2013.27

Križnik, B. (2014) Local responses to market-driven urban developmen in global cities. Teorija in praksa, 51, pp. 221-240.

Larsen, C. A. (2013) The rise and fall of social cohesion. The construction and de-construction of social trust in the USA, UK, Sweden and Denmark. Oxford, Oxford University Press.

DOI: 10.1093/acprof:oso/9780199681846.001.0001

L'Associació de Veïns (2003) Substitució social al Poblenou. El Poblenou, 9, p. 5.

Lee, J. H. (2006) Dosijaejeongbi chokjineul wihan teukbyeolbeop silhaenge isseo mingwan partnership mosaek: Seoul-si New Townui gyeongheomeul tonghaeseo. In: Seoul Development Institute (ed.) Dosijaejeongbi chokjineul wihan teukbyeolbeop jejeonge tareun Seoul-si New Town saeopui baljeonbangan yeongu, pp. 53-90. Seoul.

Lee, K. M. (2009) Saengeopttaemune jubyeon teodoljiman ... jibeun julgo binman neuleo. The Hankyoreh, 30 Sept. 2009.

Livingston, M., Bailey, N. \& Kearns, A. (2010) Neighbourhood attachment in deprived areas: Evidence from the north of England. Journal of Housing and the Built Environment, 25(4), pp. 409-427.

DOI: 10.1007/s10901-010-9196-3

Manzi, T., Lucas K., Jones, T. L. \& Allen, J. (eds.) (2010) Social sustainability in urban areas: Communities, connectivity, and the urban fabric. London, Earthscan.

Marrero Guillamón, I. (2010) The struggle for representation: Cultural artefacts and political assemblies in the conflict of Can Ricart, Barcelona. In: Degen, M. \& Miles, M. (eds.) Culture and agency: Contemporary culture and urban change, pp. 96-116. Plymouth, University of Plymouth.

Marshall, T. (2000) Urban planning and governance: Is there a Barcelona model? International Planning Studies, 5(3), pp. 299-319. DOI: $10.1080 / 713672855$

Mayer, H. \& Knox, P. L. (2006) Slow cities: Sustainable places in a fast world. Journal of Urban Affairs, 28(4), pp. 321-334.

DOI: 10.1111/j.1467-9906.2006.00298.x
Mayer, M. (2007) Contesting the neoliberalization of urban governance. In: Leitner, H., Peck, J. \& Sheppard, E. S. (eds.) Contesting neoliberalism: Urban frontiers, pp. 90-115. New York, Guildford Press.

Monclús, F. J. (2003) The Barcelona model: An original formula? From "reconstruction" to strategic urban projects (1979-2004). Planning Perspectives, 18(4), pp. 399-421. DOI: 10.1080/0266543032000117514

Nahm, K. B. (2001) The spatial structure of unplanned shopping clusters developed along the Cheonggyechon-ro and the emerging new industrial clusters. International Journal of Urban Sciences, 5(1), pp. 14-28. DOI: 10.1080/12265934.2001.9693485

OECD (2005) OECD Territorial reviews. Paris, OECD Publications.

OECD (2009) Promoting entrepreneurship, employment and business competitiveness: The experience of Barcelona. Paris, OECD Publications.

Oliva, A. (2003) El districte d'activitats 22@. Barcelona, Aula Barcelona.

Park, C. M. (2006) Local governance and community power in Korea. Korea Journal, 46(4), pp. 9-32.

Roberts, P., Sykes, H. \& Granger, R. (2017) Urban regeneration. 2nd ed. London, Sage.

Sassen, S. (2001) The global city: New York, London, Tokyo. 2nd ed. Princeton, Princeton University Press.

Seongdong-gu District Office (2006) Seongdong-gu tonggyeyeonbo 2005. Seoul.

Seoul Museum of History (2009) Wangsimni: gonggan, gyeongje, munhwa. Seoul.

Shin, H. B. \& Kim, S. H. (2016) The developmental state, speculative urbanisation and the politics of displacement in gentrifying Seoul. Urban Studies, 53(3), pp. 540-559. DOI: 10.1177/0042098014565745

Short, J. R. (2004) Global metropolitan: Globalizing cities in a capitalist world. London, Routledge.

SMG (2005) Development of new towns \& balanced development promotion. Seoul.

SMG (2010) New Town saeob 7nyeonganui girok. Seoul.

SMG (2013) Hamkke mandeulgo hamkke nurineun Seoul-si, Juminchamyeohyeong jaesaengsaeob manual. Seoul.

SMG (2015a) Seoul statistical yearbook 2015. Seoul.

SMG (2015b) 2025 Seoul-si dosi jaesaeng jeollyag gyehoeg. Seoul.

Smith, N. (2002) New globalism, new urbanism: Gentrification as global urban strategy. Antipode, 34(3), pp. 427-450.

DOI: $10.1111 / 1467-8330.00249$

Taylor, P. J. (2004) World city network, a global urban analysis. London, Routledge.

Uršič, M. \& Križnik, B. (2012) Comparing urban renewal in Barcelona and Seoul: Urban management in conditions of competition among global cities. Asia Europe Journal, 10(1), pp. 21-39. DOI: 10.1007/s10308-012-0319-1

Williams, K. \& Dair, C. (2007) A framework for assessing the sustainability of brownfield developments. Journal of Environmental Planning and Management, 50(1), pp. 23-40. DOI: 10.1080/09640560601048275

Wolfram, M. (2018) Cities shaping grassroots niches for sustainability transitions: Conceptual reflections and an exploratory case study. Journal of Cleaner Production, 173(1), pp. 11-23.

DOI: 10.1016/j.jclepro.2016.08.044 